\title{
Determinants of Firm Value: A Case Study of Cigarette Companies Listed on the Indonesia Stock Exchange
}

\author{
Ceriawati Daeli, Endri \\ Magister Manajemen, Universitas Mercu Buana, Jakarta, Indonesia \\ *Corresponding Author: Ceriawati Daeli, Magister Manajemen, Universitas Mercu Buana, Jakarta, \\ Indonesia

\begin{abstract}
The purpose of this research is to know whether there is influence of capital structure, profitability, liquidity, and market share to company value. This research was conducted on consumer goods sector of cigarette sub sector in Indonesia Stock Exchange in period 2012-2016. The population of this study are 4 companies. While the sample company taken with purposive sampling method as many as 4 companies with multiple regression analysis method. Multiple regression analysis in this research is used to see the relation between independent variable to dependent variable, either individually or together. The result of analysis shows that as long as the research of capital structure and profitability have positive and significant influence to firm value. While liquidity has a negative and insignificant influence on the value of the company. Other results also show that market share has a positive but insignificant effect on firm value.
\end{abstract}

Keywords: Entreprise value, capital structure, profitability, liquidity, market share

\section{INTRODUCTION}

The value of a company can reflect the value of assets owned by a company such as securities that are important for company management, considering the value of the company because it is related to the interests of the owner of the company in maximizing its welfare (Endri, 2018a). Company value can describe the state of the company. With the good value of the company, the company will be considered good by potential investors, and vice versa. Increasing the value of the company can be achieved if there is cooperation between the management of the company and other parties which include sharehoders and stakeholders in making financial decisions with the aim of maximizing working capital owned (Raheman et al., 2010). Maximizing company value is very important for the company, because maximizing the value of a company means maximizing shareholder prosperity which is the company's main goal. While the company's value will be reflected in the stock market price (Ding et al., 2006). The higher the value of the company, the greater the prosperity that the owner of the company will receive. For companies that issue shares in the capital market, the share price traded on the stock exchange is an indicator of the company's value.

\section{THEORETICAL BACKGROUND}

\subsection{Entreprise Value}

In making financial decisions, financial managers need to determine goals to be achieved. The right financial decisions can maximize the value of the company so as to increase the prosperity of the company owner. The value of the company itself is the price that is willing to be paid by prospective buyers if the company is sold. According to Fama and French (2015), company value can be seen from the stock price. Share prices are formed at the request and offer of investors, so that the stock price can be used as a proxy for the company's value. High stock prices make the value of the company also high. High company value will make the market believe not only in the company's current performance but also in the company's prospects in the future. To maximize the value of the company, not only the equity value is considered, but financial sources such as debt and preferred shares. 


\subsection{Capital Structure}

Capital structure is equity and debt funding in a company. According to Fama and French (2002), said that the optimization of corporate value which is the company's goal can be achieved through the implementation of financial management functions, where every financial decision taken will influence other financial decisions and have an impact on the company's value. Franco Modigliani and Merton Miller (MM) introduced a model of capital structure theory mathematically, scientifically and on the basis of continuous research. Please note that MM introduces capital structure theory with the following assumptions: 1) no tax. 2) investors can borrow at the same level as the company. 3) information is always available to all investors and can be obtained at no cost. 4) EBIT does not affect debt use.

\subsubsection{Trade of Theory}

In addition to the theory proposed by MM (Modigliani and Miller) there are still other capital structure theories that discuss the relationship between capital structure and firm value. According to the trade-off theory expressed by Myers (2001: 81), "Companies will be indebted to a certain level of debt, where tax savings (tax shields) from additional debt equals the cost of financial difficulties (financial distress). The cost of financial difficulties (financial distress) is bankruptcy costs or reorganization, and agency costs are increased due to the decline in the credibility of a company. The trade-off theory in determining the optimal capital structure includes several factors, including taxes, agency costs and financial distress, but still maintains the assumption of market efficiency and symmetric information in the balance and benefits of using debt. As far as benefits are greater, additional debt is still allowed. If the sacrifice due to the use of debt is greater, then additional debt is not allowed.

\subsection{Profitability}

Profitability or profit is income less expenses and losses during the reporting period. Analysis of profitability is very important for creditors and equity investors. For creditors, profit is the source of interest payments and principal loans. Whereas for equity investors, profit is one of the determinants of changes in securities value. The most important thing for a company is how it can maximize shareholders not how much profit is generated by the company.

According to Endri (2012), the profitability of a company is one way to appraise precisely the extent of return that will be obtained from its investment activities. Profitability can reflect the benefits of financial investment, meaning that profitability affects the value of the company due to the growing internal resources (Sudarma, 2004) in Lifessy. The better the growth of the company's profitability means that the prospects of the company in the future are better, meaning that the value of the company will also be considered better in the eyes of investors. If the company's ability to generate profits increases, then the stock price will also increase (Husnan, 2001: 317). The higher profitability means the better, because the prosperity of the owner of the company increases with higher profitability.

\subsection{Liquidity}

Liquidity is the company's ability to meet its short-term obligations. Liquidity is one of the factors that determine a company's success or failure. Provision of cash needs and resources to meet these needs also determines where the company holds risks. Another definition is the company's ability to fulfill obligations or debt that must immediately be paid with its current assets. Endri (2016) states that: "liquidity is related to the problem of a company's ability to fulfill its financial obligations which must immediately be met. The amount of payment instruments (liquid equipment) owned by a company at one time is the paying power of the company concerned ".

\subsection{Market Share}

According to Neo-Classical literature, the foundation of the company's bargaining position is the market share it achieves. Market share in business practices is the company's goal / motivation. Companies with a better market share will enjoy the benefits of product sales and rising stock prices (Naylah, 2010). The role of market share as well as other market structure elements is a source of profit for the company. Thus it can be seen that market share has become a strong indication in 
assessing market forces. It is clear that if a large share is high, the company is very influential on the market, and vice versa if the market share is low then the power to influence the market is very low.

Market share is defined as the percentage of sales that can be achieved by a company and all available potential. The market share reflects the superiority of a company's competitive position compared to other companies. Growth in market share can be measured by comparing the increase in market share and year to year (Cravens and Piercy, 2009: 90). Company sales do not reveal how well the company is compared to competitors. Therefore management needs to track its market share. The market share is used to explain the position of companies in an industry, as expressed by Kaplan and Norton. (2000: 60) that market share describes business propositions that are sold by a business unit in a particular market (in the form of the number of customers, the money spent, or the volume of units sold).

\subsection{Hypothesis}

\subsubsection{Effect of Capital Structure on Entreprise Value}

Trade off theory states that there is an optimal capital structure that is a capital structure that can increase the value of the company, which is achieved if the company is able to balance the benefits of using debt with bankruptcy and agency costs, then any additional debt will increase the value of the company. The use of debt will increase the value of the company but only up to a certain point, after that point the use of debt will actually reduce the value of the company because the increase in profits from the use of debt is not proportional to the increase in costs of financial distress and agency problems (Endri 2018b). Thus the trade off theory views the influence of capital structure on the value of a company. Supporting research has been carried out by Eka (2010), Deli and Kurnia (2017), Manopo \& Arie (2016) found that capital structure influences firm value. From the description above, the first hypothesis of this study is:

H1: Capital structure has a positive effect on Entreprise value

\subsubsection{Effect of Profitability on Entreprise Value}

The strength of earnings refers to the level of earnings that are expected to occur in the future. Profitability is recognized as the main factor in the company's valuation (Endri, 2018b). Profitability or profit is an attraction for investors before investing in the company. Investors will first see the level of profitability to assess value. According to Sartono (2011:7) revealed that: "To increase the value of the company that is done is by maximizing profit." As revealed by Brigham and Houston (2014) that: "High profit will be able to trigger investors to increase demand for shares, so that increased stock demand will cause the company's value to increase. "Many argue that profitability greatly affects the value of the company. As observed by Dewi and Wirajaya (2013), Manoppo and Arie (2016), Haryadi (2016), Suffah and Riduwan (2016), Dhani and Utama (2017), Deli and Kurnia (2017) which reveal that profitability affects the value of the company. From the description above, the second hypothesis of this study is:

H2: Profitability has a positive effect on Entreprise value

\subsubsection{Effect of Liquidity on Entreprise Value}

Liquidity is the ratio used to measure a company's ability to pay short-term obligations (Endri, 2016). According to Pecking order theory, companies that have high liquidity will tend not to use debt financing because they have large funds for internal funding. The use of alternative funding starts from the securities that are least risky, namely retained earnings, debt and then the issuance of new shares. Retained earnings are reinvested in the hope of increasing corporate profits in the coming year. Nurhayati (2013) said that companies with large liquid assets can use these assets to invest.

A high asset liquidity ratio can be considered by investors to be a positive signal because it indicates that the company can meet its current liabilities and is faced with a low risk of bankruptcy. With large retained earnings, companies will prefer to use retained earnings for company operations before using debt or issuing new shares. Profits not distributed as dividends will be used for expansion which usually means asset purchases. This is consistent with the pecking order theory which says that managers prefer to use financing with the first order of retained earnings, then debt and finally the sale of new shares. As studied by Amihud (2007), Ferlen et al., (2015), Endri (2016), which prove that 
liquidity has a negative effect on firm value. From the description above, the third hypothesis of this study is:

H3: Liquidity has a negative effect on the value of the Entreprise value

\subsubsection{Effect of Market Share on Entreprise Value}

Market Share can be interpreted as part of a market that is controlled by a company, or the percentage of a company's sales to the total sales of its biggest competitors at a particular time and place (William, 1984). If a company with a certain product has a market share of $35 \%$, it means that if the total sale of similar products in a certain period is 1000 units, then the company through its product will get sales of 350 units. The magnitude of market share at any time will change according to changes in consumer tastes, or the transfer of consumer interest from a product to another product (Doukas and Lorne, 1992). Supporting research has been carried out by Madden (2006), and Jumono et al., (2015), which prove that Market Share affects the value of a company. From the description above, the third hypothesis of this study is:

H4: Market Share has a positive effect on the value of the Entreprise value

\section{RESEARCH METHODOLOGY}

\subsection{Population}

According to Sugiyono (2011) population is an area of generalization consisting of objects or subjects that have certain qualities and characteristics set by researchers to be studied and then drawn conclusions. The population in this study are all companies engaged in the Cigarette Sub-Sector in 2012-2016.

\subsection{Sample}

According to Sekaran (2011: 123) the sample is part of the population. The sample consists of a number of members selected from the population. The sampling method uses nonprobability sampling. Nonprobability sampling is a sampling technique that does not provide an opportunity or equal opportunity for each element or member of the population to be selected as a sample (Sugiyono, 2011: 125). The sample technique used in this study was purposive sampling. Purposive sampling is a sample determination technique with certain considerations (Sugiyono, 2011: 126). The criteria that have been determined in the sample selection are as follows:

\begin{tabular}{|c|l|c|}
\hline No & \multicolumn{1}{|c|}{ Criteria } & \multicolumn{1}{|c|}{ Amount } \\
\hline 1 & Cigarette Sub-Sector Companies listed on the Indonesia Stock Exchange (IDX) & 4 \\
\hline & The number of samples made as research objects & 4 \\
\hline
\end{tabular}

Source: Indonesia Stock Exchange, processed

From the above criteria, 4 companies were obtained with a 5-year study period, so that 20 observations were obtained.

\subsection{Panel Data Regression Analysis}

Panel Data Regression Analysis is used to test the hypotheses that have been proposed in the study. With this approach it will be able to know how much influence the variables of capital structure, profitability, and liquidity on the value of the cigarette sub-sector companies listed on the Indonesia Stock Exchange (IDX). Panel data is a combination of cross section and time series. Panel data regression models can be formulated as follows:

$\mathrm{Y}_{\text {it }}=\alpha+\beta \mathrm{X}_{\text {it }}+\varepsilon_{\text {it }} ; \quad \mathrm{i}=1,2, \ldots \ldots ., \mathrm{N} ; \quad \mathrm{t}=1,2, \ldots \ldots \mathrm{T}$

Information:

$\mathrm{N}=$ Number of observations

$\mathrm{T}=$ Amount of time

$\mathrm{N} \times \mathrm{T}=$ Number of panel data 
Determinants of Firm Value: A Case Study of Cigarette Companies Listed on the Indonesia Stock Exchange

\section{RESEARCH RESULTS AND DISCUSSION}

\subsection{Descriptive Statistics Analysis}

Table1. Descriptive Statistics of Research Variables

\begin{tabular}{|c|c|c|c|c|c|}
\hline VARIABEL & 2012 & 2013 & 2014 & 2015 & 2016 \\
\hline $\mathrm{N}$ & 20 & 20 & 20 & 20 & 20 \\
\hline PBV & \multicolumn{5}{|c|}{ Price to Book Vale } \\
\hline Mean & 7,1025 & 7,1375 & 3,8000 & 4,0575 & 5,1325 \\
\hline Maximum & 19,73 & 19,32 & 27,35 & 13,66 & 14,51 \\
\hline Minimum & 2,18 & 1,80 & $-17,41$ & $-1,17$ & 0,96 \\
\hline Std. Dev. & 8,45997 & 8,20958 & 18,34236 & 6,60205 & 6,32425 \\
\hline DER & \multicolumn{2}{|c|}{ Debt to Equity Ratio } & & & \\
\hline Mean & 1,2425 & 2,9275 & $-1,4825$ & $-0,9350$ & 0,4075 \\
\hline Maximum & 2,60 & 9,47 & 1,10 & 0,67 & 0,59 \\
\hline Minimum & 0,56 & 0,57 & $-8,34$ & $-5,02$ & 0,24 \\
\hline Std. Dev. & 0,92103 & 4,36430 & 4,57713 & 2,73038 & 0,14523 \\
\hline ROA & \multicolumn{2}{|l|}{ Return on Assets } & & & \\
\hline Mean & 12,3575 & 11,8950 & 7,8325 & 8,5600 & 8,2450 \\
\hline Maximum & 37,89 & 39,48 & 35,87 & 27,26 & 30,02 \\
\hline Minimum & $-4,66$ & $-11,29$ & $-22,23$ & $-12,94$ & $-15,48$ \\
\hline Std. Dev. & 18,10650 & 20,89996 & 23,75056 & 16,49182 & 18,64297 \\
\hline $\mathrm{CR}$ & \multicolumn{3}{|l|}{ Current Ratio } & & \\
\hline Mean & 191,2725 & 177,0850 & 160,6125 & 335,8725 & 324,1975 \\
\hline Maximum & 217,02 & 243,00 & 227,49 & 656,74 & 523,41 \\
\hline Minimum & 164,27 & 117,87 & 100,17 & 177,04 & 193,78 \\
\hline Std. Dev. & 24,51517 & 51,24549 & 52,24743 & 218,85608 & 146,04224 \\
\hline MS & \multicolumn{2}{|l|}{ Market Share } & & & \\
\hline Mean & 14,8875 & 18,3075 & 20,3350 & 22,6225 & 23,8225 \\
\hline Maximum & 16,37 & 20,11 & 21,04 & 23,30 & 26,37 \\
\hline Minimum & 13,51 & 17,17 & 19,83 & 21,89 & 21,35 \\
\hline Std. Dev. & 1,28909 & 1,31378 & 0,58836 & 0,66665 & 2,06697 \\
\hline
\end{tabular}

Source: data processed with reviews 9

The dependent variable Price to Book Value has a Mean value between 5.1325 to 7.1375 which indicates that a high stock price makes the value of the company also high, a high company value will make the market believe not only in the company's current performance but also in the company's prospects in the future 5.13\% to $7.13 \%$ of total assets. Maximum PBV value of 27.35 PT Handjaya Mandala Sampoerna Tbk. (HMSP) in 2014 and a minimum value of -1.17 from PT. Bentoel Internasional Investama Tbk. (RMBA) in 2015 with a standard deviation between 6,32425 to 18,34236 .

The independent variable Debt to Equity Ratio has a Mean value between $-9,350$ to 2,9275, the average DER value shows that the average cigarette company has a debt of $-9.35 \%$ to $2.92 \%$ with a maximum value of 9.47 of PT. Bentoel Internasional Investama Tbk. (RMBA) in 2013 and a minimum value of -5.02 from PT. Bentoel Internasional Investama Tbk. (RMBA) which suffered losses in 2015, with a variable standard deviation of 0.92103 to 4.57713 . this company seems to have a much larger amount of debt compared to other companies in the market, however in the five years up to 2016 the company's DER trend has been relatively declining which also indirectly shows that the company is trying every year to reduce its debt level to the point that lower, in general a DER value of more than 1 gives a greater risk associated with the ability of a company to pay, this is because the level of the company is even greater than its equity.

The independent variable Return on Assets has a Mean value between 7.8325 and 12.3575 which indicates that the cigarette company is able to generate an operating profit of $7.83 \%$ to $12.35 \%$ of the total assets owned. Maximum Profitability value of 39.48 from PT Handjaya Mandala Sampoerna Tbk. (HMSP) in 2013 and a minimum value of -4.66 from PT. Bentoel Internasional Investama Tbk. (RMBA) in 2012 with a standard deviation between 16.49182 to 23.75056 . 
The independent variable current ratio has a mean value between 160.6125 to 335.8725 . The average value of CR shows that the average current assets of cigarette companies are able to guarantee the company's current liabilities of 160.61 percent to 335.87 percent. The maximum current ratio value is 656.74 from PT Handjaya Mandala Sampoerna Tbk. (HMSP) in 2015 and a minimum value of 100.17 from PT. Bentoel Internasional Investama Tbk. (RMBA) in 2014 with a standard deviation between 24,51517 to 218,85608 .

The independent market share variable has a mean value between 14.8875 to 23.8225 . This shows that the tobacco companies in the sample studied had an average sales value growth of between $14.88 \%$ to $23.82 \%$ from the previous year. Market Share Value is a maximum of 26.37 PT. Bentoel Internasional Investama Tbk. (RMBA) in 2016 and a minimum value of 13.51 from PT. Bentoel Internasional Investama Tbk. (RMBA) in 2012 with a standard deviation between 0.58836 to 2.06697 .

\subsection{Panel Data Regression Model Selection}

\subsubsection{Chow Test or Common Effect vs. Fixed Effect}

Chow Test is used to select the right panel data regression model to test which model is best used in the research between Common Effect models or Fixed Effect models.

Table2. Chow Test

\begin{tabular}{|c|r|r|r|}
\hline Effects Test & Statistic & d.f. & \multicolumn{1}{c|}{ Prob. } \\
\hline Cross-section F & 5.722597 & $(3,12)$ & 0.0114 \\
\hline Cross-section Chi-square & 17.763168 & 3 & 0.0005 \\
\hline
\end{tabular}

Source: data processed with eviews 9

Based on the Chow test using e-views in Table 2 obtained $\mathrm{F}$ test and chi-square test smaller than $\alpha=$ $0.05(5 \%)$ that is equal to 0.0005 . This test yields the conclusion that $\mathrm{H} 0$ is rejected and $\mathrm{H} 1$ is accepted, which means that Fixed Effect is better used in estimating panel data regression than Common Effect.

Table3. Analysis of Data Panel Regression Estimation with the Fixed Effect Model Method

\begin{tabular}{|c|r|r|r|r|}
\hline Variable & Coefficient & Std. Error & t-Statistic & Prob. \\
\hline C & -2.772927 & 6.485840 & -0.427536 & 0.6751 \\
\hline DER & 0.801206 & 0.344250 & 2.327395 & 0.0344 \\
\hline ROA & 0.454126 & 0.065541 & 6.928861 & 0.0000 \\
\hline MS & -0.004547 & 0.009130 & -0.498090 & 0.6256 \\
\hline R-squared & 0.225746 & 0.343973 & 0.656290 & 0.5216 \\
\hline Adjusted R-squared & 0.822426 & Mean dependent var & 5.446000 \\
\hline S.E. of regression & 0.775073 & S.D. dependent var & 9.509949 \\
\hline Sum squared resid & 4.510236 & Akaike info criterion & 6.062894 \\
\hline Log likelihood & 305.1334 & Schwarz criterion & 6.311827 \\
\hline F-statistic & -55.62894 & Hannan-Quinn criter. & 6.111488 \\
\hline Prob(F-statistic) & 17.36794 & Durbin-Watson stat & 1.006348 \\
\hline
\end{tabular}

Based on the results of multiple regression analysis above, a regression line equation can be obtained as follows:

$\mathrm{PBV}=-2.772927+0.801206(\mathrm{DER})+0.454126(\mathrm{ROA})+-0.004547(\mathrm{CR})+0.225746(\mathrm{MS})$

The above equation can be interpreted as follows:

1. The constant $\mathrm{C}$ of -2.772927 states that if the variables DER, ROA, CR and MS are constant, the Price to Book Value (PBV) variable is -2.772927 .

2. DER regression coefficient of 0.801206 states that every increase in Debt to Equity Ratio (DER) of $1 \%$ will have an impact on increasing Price to Book Value (PBV) of 0.801206 assuming other independent variables are of constant magnitude.

3. ROA regression coefficient of 0.454126 states that every increase in Return On Assets of $1 \%$ will have an impact on increasing Price to Book Value (PBV) of 0.454126 assuming other independent variables are of constant magnitude. 
4. The CR regression coefficient of -0.454126 states that any increase in Current Ratio (CR) of $1 \%$ will have an impact on increasing Price to Book Value (PBV) of -0.454126 assuming other independent variables are of constant magnitude.

5. MS regression coefficient of 0.225746 states that every increase in Market Share (MS) of $1 \%$ will have an impact on a decrease in Price to Book Value (PBV) of 0.225746 assuming other independent variables are of constant magnitude.

\subsubsection{Test of Goodnes of Fit (R2)}

Panel data regression estimation results in Table 3 with Fixed Effect model for testing goodness of fit, shows the coefficient of determination $\mathrm{R}^{2}=0.822426$ which means that all Independent Variables; Debt to Equity Ratio (DER), Return on Assets (ROA), Current Ratio (CR) and Market Share (MS) can explain the variation of the rise and fall of Price to Book Value of tobacco companies by $82.24 \%$, while the remaining $17.76 \%$ is explained by other factors not included in this model. While the determination coefficient value adjusted $\mathrm{R}^{2}=0.775073$, which means that after considering the degree of freedom, all Independent Variables used in this study were able to explain the variation that occurred in the Price to Book Value of tobacco companies by $77.50 \%$.

\subsubsection{Hypothesis Testing}

\section{Simultaneous Significance Test (Test Statistics F)}

Research conducts significant simultaneous testing (overall significance) on a regression equation based on hypothesis testing. Based on the results of the statistical data processed in Table 3, it can be seen the Prob value (F-Statistics) is 17.36794 smaller than $\alpha=0.05$, which means that $\mathrm{H} 0$ is rejected and $\mathrm{Ha}$ is accepted. This shows that the independent variables Debt to Equity Ratio (DER), Return on Assets (ROA), Current Ratio (CR) and Market Share (MS) have a significant effect jointly on the Price to Book Value (PBV) of cigarette companies every year.

\section{Partial Test}

Partially based on Table 3, it can be seen that the influence between the independent variables on the dependent variable is as follows:

1. Debt to Equity Ratio (DER), has a positive $\beta$ coefficient of 0.801206 with a tcount of 2.327395 and a significance value of 0.0344 smaller than 0.05 so that the first hypothesis can be accepted. This means that the variable Debt to Equity Ratio has a positive and significant effect on Price to Book Value of cigarette companies.

2. Return on Assets (ROA), has a positive $\beta$ coefficient of 0.454126 with a tcount of 6.928861 and a significance value of 0.0000 smaller than 0.05 so that the second hypothesis can be accepted. This means that the Return on Assets variable is proven to have a positive and significant effect on the Price to Book Value of cigarette companies.

3. Current Ratio (CR) has a negative $\beta$ coefficient of -0.004547 with a tcount of -0.498090 and a significance value of 0.6256 greater than 0.05 so that the third hypothesis is not acceptable. This means that the Current Ratio variable is proven to be insignificant. Price to Book Value of tobacco companies.

4. Market Share has a positive $\beta$ coefficient of 0.225746 with a tcount of 0.656290 and a significance value of 0.5216 greater than 0.05 so that the fourth hypothesis cannot be accepted. This means that the Market Share variable is proven to be insignificant Price to Book Value of cigarette companies.

\section{CONCLUSION}

Based on the description of the research results in the previous chapter, the following conclusions can be drawn:

- Debt to Equity Ratio (DER) proved to have a positive and significant effect on Price to Book Value in the cigarette industry sub-sector for the 2012-2016 period.

- Return on Assets (ROA) proved to have a positive and significant effect on Price to Book Value in the cigarette industry sub-sector for the period 2012-2016. 
- Curren Ratio proved to have a negative and insignificant effect on Price to Book Value in the cigarette industry sub-sector for the period 2012-2016.

- Market Share has a positive but not significant effect on Price to Book Value in the cigarette industry sub-sector for the period 2012-2016.

This research is expected to provide various benefits for the parties involved, including:

- For cigarette companies listed on the Stock Exchange that profitability is important to pay attention to increase the value of the company. Companies can do this by increasing the company's ability to make profits through all available sources, sales, cash, assets and capital.

- For investors profitability is not the only factor used to increase the value of the company, but investors must pay attention to the capital structure and liquidity and market share of the company.

- For similar companies, the results of research on cigarettes listed on the IDX can be used as a comparison, so that it can be known the advantages and disadvantages so that improvements can be made to increase the value of the company.

\section{REFERENCES}

[1] Amihud, Y., Mendelson, H., 2008. Liquidity, the Value of the Firm, and Corporate Finance. Journal of Applied Corporate Finance 20, 32-45.

[2] Brigham, E. F., \& Houston, J. F. 2014. Dasar-dasar Manajemen Keuangan. Buku 2. Edisi 11. Jakarta : Salemba Empat.

[3] Cravens, D.W. and Piercy, N.F. 2006. Strategic Marketing, (8th ed.). NY: Mc Graw Hill.

[4] Doukas, John and Lorne Switzer (1992), "The Stock Market's Valuation of R\&D Spending and Market Concentration," Journal of Economics and Business, 44, 95-114.

[5] Ding S, Guariglia A, Knight J. 2012. Investment and financing constraints in China: does working capital management make a difference? Journal of Banking \& Finance. 37(5):1490-1507.

[6] Dewi, A. S. M., \& Wirajaya, A. 2013. Pengaruh Struktur Modal, Profitabilitas, dan Ukuran Perusahaan pada Nilai Perusahaan. E-Jurnal Akuntansi Universitas Udayana 4.2, 358- 372.

[7] Dhani dan Utama (2017) Pengaruh Pertumbuhan Perusahaan, Struktur Modal, Dan Profitabilitas Terhadap Nilai Perusahaan, Jurnal Riset Akuntansi dan Bisnis Airlangga Vol. 2. No. 1(2017) 135-148 ISSN.

[8] Dewi,Ayu Sri Mahatma dan Ary Wirajaya . 2013 ." Pengaruh Struktur Modal, Profitabilitas dan Ukuran Perusahaan terhadap Nilai Perusahaan". E-Journal Akuntansi Universitas Yudayana, 358-372.

[9] Deli dan Kurnia. 2017. Pengaruh Struktur Modal, Profitabilitas, Growth Opportunity Dan Likuiditas Terhadap Nilai Perusahaan, Jurnal Ilmu dan Riset Akuntansi, 6(7): 153-165

[10] Endri. 2012. Pengaruh Mekanisme Corporate Governance Terhadap Kinerja Profitabilitas Perbankan Syariah di Indonesia, Jurnal Keuangan dan Perbankan, 16(2): 264-274.

[11] Endri. 2016. Dampak Perubahan Satuan Perdagangan dan Fraksi Harga Terhadap Likuiditas Saham, MIX: Jurnal Ilmiah Manajemen, 6(1), 56-69

[12] Endri. 2018a. Factors Determine Stock Return of Livestock Feed Companies: Common Effect Model Analysis. International Journal of New Technology and Research (IJNTR), 4(5), 106-113.

[13] Endri. 2018b. Prediction of Bankruptcy Potential Company of Drinking Water Region. International Journal of Business and Management Invention (IJBMI), 7 (5), 75-85

[14] Eka Lestari, Putu. 2010. Pengaruh Struktur Modal dan Kepemilikan Manajerial Serta Ukuran Perusahaan terhadap Nilai Perusahaan pada Perusahaan Manufaktur di Bursa Efek Indonesia. Skripsi Fakultas Ekonomi Universitas Udayana.

[15] Fama, E.F. and French, K.R. 2015. A Five-Factor Asset Pricing Model. Journal of Financial Economics, $116,1-22$.

[16] Ferlen Timbuleng \& Sientje C. Nangoy \& Ivonne S. Saerang. (2015). Pengaruh Faktor Likuiditas, Leverage, NPM Dan ROI Terhadap Nilai Perusahaan. Jurnal EMBA Vol.3 No.2, ISSN 2303-1174

[17] Fama, Eugene F., and Kenneth R.French, 2002, Testing Trade Off and Pecking Order Predictions About Dividens and Debt, The Review of Financial Studies, Vol.15, No.1, pp.1-33.

[18] Husnan, Suad. 2001. Dasar-Dasar Teori Portofolio dan Analisis Sekuritas. Yogyakarta : Unit Penerbit dan Percetakan AMP YKPN.

[19] Haryadi. 2016. Pengaruh Sizeperusahaan, Keputusan Pendanaan, Profitabilitas Dan Keputusan Investasi Terhadap Nilai Perusahaan, Jurnal Akuntansi. Vol. 3 No. 2. Juli 2016 ISSN 2339-2436. 
[20] Jumono, Sapto., Abdurrahma., Amalia, Lia., 2013. Deteksi Praktis Aplikasi POT (Pecking Order Theory)., Jurnal Ekonomi, Volume 4 Nomor 1, Mei 2013

[21] Kaplan, Robert S. dan David P. Norton. 2000. "Balanced Scorecard: Menerapkan strategi menjadi aksi", Erlangga, Jakarta.

[22] Madden, Thomas J., Frank Fehle, and Susan Fournier (2006), "Brands Matter: An Empirical Demonstration of the Creation of Shareholder Value through Branding," Journal of the Academy of Marketing Science, 34(2), 224-235.

[23] Manoppo, H., \& Arie, F. V. (2016). "Pengaruh Struktur Modal, Ukuran Perusahaan Dan Profitabilitas Terhadap Nilai Perusahaan Otomotif Yang Terdaftar Di Bursa Efek Indonesia Periode 2011-2014”, Jurnal Riset Ekonomi, Manajemen, Bisnis Dan Akuntansi, 4(2).

[24] Nayla, Maal (2010). Pengaruh Struktur Pasar Terhadap Kinerja Industri Perbankan Indonesia, Tesis, Fakultas Ekonomi: Universitas Diponegoro Semarang.

[25] Myers, Stewart C. 2001. Capital structure, Journal of Economic Perspectives 15 (2) pp. 81-102

[26] Nurhayati, M. (2013). Profitabilitas, Likuiditas, dan Ukuran Perusahaan Pengaruhnya Terhadap Kebijakan Dividen dan Nilai Perusahaan Sektor Non Jasa. Jurnal Keuangan dan Bisnis. Vol. 5 No. 2, 144-153

[27] Raheman A, Afza T, Qayyum A, Bodla MA. 2010. Working capital management and corporate performance of manufacturing sector in Pakistan. International Research Journal of Finance and Economics. 47:151-163.

[28] Suffah, Rofiqotus dan Akhmad Riduwan. 2016. Pengaruh Profitabilitas, Leverage, Ukuran Perusahaan dan Kebijakan Dividen pada Nilai Perusahaan. Jurnal Ilmu dan Riset Akuntansi. 5(2). 1-17.

[29] Sudarma, Made. 2003. Pengaruh Struktur Kepemilikan Saham, Faktor Intern, Faktor Ekstern, Terhadap struktur modal dan nilai perusahaan, Disertasi Program Pasca Sarjana Universitas Brawijaya Malang.

[30] Sartono, Agus. 2010. Manajemen Keuangan Teori dan Aplikasi (4 th ed.). Yogyakarta: BPFE.

[31] Sugiyono. 2013. Metode Penelitian Kuantitatif Kualitatif dan R \& D. Bandung : Alfabeta.

[32] Sekaran, Uma. (2011). Research Methods for business Edisi I and 2. Jakarta: Salemba Empat.D.

[33] William J. Stanton. 1984. Prinsip Pemasaran. Jakarta. Erlangga.

\section{AUTHORS' BIOGRAPHY}

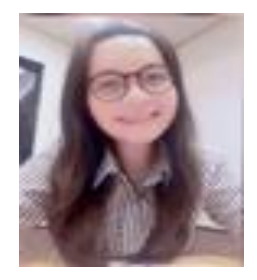

Ceriawati Daeli, a Master of Management student at Mercu Buana University Postgraduate Program, Jakarta Indonesia.

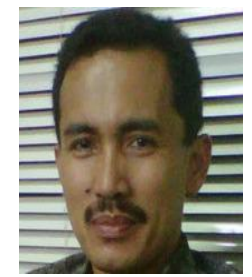

Dr. Endri, is a senior lecturer at Mercu Buana University Postgraduate Program, Jakarta - Indonesia. He has written many articles in local and international journals and specialists in the fields of Financial and Banking Management. He also developed and researched in the field of Islamic Finance and Banking.

Citation: Ceriawati Daeli \& Endri. “ Determinants of Firm Value: A Case Study of Cigarette Companies Listed on the Indonesia Stock Exchange" International Journal of Managerial Studies and Research (IJMSR), vol 6, no. 8, 2018, pp. 51-59. doi:http://dx.doi.org/10.20431/2349-0349.0608006.

Copyright: () 2018 Authors. This is an open-access article distributed under the terms of the Creative Commons Attribution License, which permits unrestricted use, distribution, and reproduction in any medium, provided the original author and source are credited. 